Tsotne Zhghenti,

Ph.D., Associate Professor, Business and Technology University, Georgia

ORCID ID: 0000-0002-6779-172X

email: tsotne.zhghenti@btu.edu.ge

Vakhtang Chkareuli,

Associate Professor, Business and Technology University, Georgia

(iD) ORCID ID: 0000-0001-9484-2484

email: vakhtang.chkareuli@btu.edu.ge

Correspondence author: tsotne.zhghenti@btu.edu.ge

\title{
ENHANCING ONLINE BUSINESS SECTOR: DIGITAL TRUST FORMATION PROCESS
}

Abstract. The paper reviews Georgia's digital trust formation process and underlines the most important challenges for the online business sector. This research can be generalized for most developing countries where the digital transition process is on the agenda, especially for countries that have recently emerged from economic-political transition. Georgia has completed the transition from a centrally planned economic system (the heritage of being part of the Soviet Union) to a free market economy. Although trust in institutions is improving gradually, mistrust in business processes is still a great challenge for local business sectors. A wide-reaching lockdown caused by the 2020-2021 COVID-19 pandemic pushed both firms and individuals further towards online activity worldwide. In this regard, trust has become the key determinant in facilitating electronic transactions. Technological advances are providing dozens of tools to improve customer satisfaction and trust, which should lead to customer loyalty. On the other hand, lack of digital skills and digital security problems raises digital untrust concerns. Therefore, trust research in the digital economy is becoming more actual for academic or business studies. Digital trust is a multidimensional factor that is under the influence of digital and physical operations. In Georgia, businesses have to overcome obstacles built-in people's minds as a heritage of the Soviet Union. Georgia was a part of the Soviet Union for 70 years, which critically degraded the trust of both formal and informal institutions. Therefore, building digital trust in business is getting more complex as it includes traditional trust problems and digital challenges too. The main research purpose in this paper is to present the digital trust forming process in Georgia to reveal the major problems. This study involved the trust stack model in analysing three different stages of trust formation in the Georgian digital economy (trust in the idea, trust in the platform, trust in the individual). The research identified challenges and steps which should be carried out soon. Research academic findings and methodological approaches can be used to analyze other developing countries whose economies are influenced by the digital transformation process.

Keywords: digital economy, digital trust, digital business, informal institutions, trust distribution.

Introduction. The digital economy had become an important part of the world economy starting from the late 20th century. However, the digitalization process has never been more important than now due to rapid technological advances and growing innovations in business.

The digital gap between developed and developing countries becomes more challenging for developing economies, including the Georgian economy. Digital trust is a key instrument connecting individuals, businesses, and institutions in the current digital world. Therefore, studying digital trust is crucial for the academic sector to understand the digital economy. The digital trust concept is evolving, i.e., it is partially unexplored, especially in developing economies where statistical data or theoretical basis are not available for country level. Even as digital trust is a new concept, the transition process from traditional trust to digital trust pays attention on trust deep foundations. Unfortunately, no academic studies have not published from Georgian academic society about digital trust forming process.

Cite as: Zhghenti, T., \& Chkareuli, V. (2021). Enhancing Online Business Sector: Digital Trust Formation Process. Marketing and Management of Innovations, 2, 87-93. http://doi.org/10.21272/mmi.2021.2-07 
Nowadays, on a governmental level, Georgia cooperating with various donor organizations (such as the World Bank, EU4Digital, etc.) is undertaking various programs to develop and upgrade the infrastructure for the digital economy. For example, «The State Programme on Broadband Infrastructure Development in Georgia» focuses on establishing broadband internet infrastructure (places out of a fiberoptic network will be covered using fiber-optic cables and established open access points). Besides that, the European Union's EU4Digital Initiative supports digital reform in Georgia to promote key areas of the digital economy and society in line with EU norms and practices. These programs will lead us to a stronger digital economy and improve Georgia's potential in business, entrepreneurship, tourism, ICT industry, and innovation. On the other hand, trust deep foundations are very important in studying the digital trust forming process. Notably, Georgia was a part of the Soviet Union for 70 years, where the government made all economic, political and social decisions. It was a system with a different, previously unknown, and unique trust distribution process. A system of centrally planned economic activities (including labor and capital allocation, planned supply of goods and services with prices set by governmental institutions rather than supply and demand) was intended to relocate trust from society to the government. Indeed, a society, which lacks private institutions and individual autonomy is artificially bound to government. The problem is that people cannot command each other to trust in ideas, beliefs, or government. Lack of business relations strengthens the concept of having trust only in government organizations, but practically it can't work effectively. Trust should be formed based on personal experience and information rather than by force from policymakers. After the early 1990s dissolution of the USSR, Georgia suffered from unsustainable socio-economic conditions (deep economic recession, hyperinflation, civil war, military conflicts, high unemployment rates, etc.). From an institutional perspective, there was a tremendous loss of trust in untrustworthy new or old institutions. People had lost their belief that the government could serve their interests. The Georgian economy faces challenges during digital transformation, which could be similar to many countries worldwide adopting digital technologies in the real economy. Therefore, the paper aims to review the digital trust forming process in the Georgian economy.

Literature Review. Trust plays a major role in modern economic transactions and the institutional building process. Trust is strongly linked to the concept of uncertainty which creates motivation for trust. To understand the importance of trust, first, it is required to overview the concept of uncertainty. The pioneer in institutional economics, Douglass North, spotlighted interactions between uncertainty and institutions. The researcher argued that institutions are humanly devised constraints to create order and reduce uncertainty in exchange (North, 1999). Humans throughout history have always tried to reduce the uncertainty associated with the physical environment. But if uncertainty associated with the physical environment has declined, the human environment has become more complex (Groenewegen, 2010).

Uncertainty is the fundamental motivation factor in the trust-building process. One of the general characteristics of trust is that it exists in an uncertain and risky environment (Bhattacharya et al., 1998). Niklas Luhmann suggested that trust presupposes a situation of risk (Luhmann, 1988). Kenneth Arrow indicated that virtually every commercial transaction has an element of trust (Arrow and Hurwicz, 1972). Modern trust researcher Rachel Botsman described trust as an essential factor in dealing with uncertain situations - «that pulls you over the gap between certainty and uncertainty» (Botsman, 2017). The institutional role in long-term economic development became crucial during the last few decades. It raised the significance of the trust concept as an informal institution too. Scholars started to agree that entrepreneurs had not produced sustained economic growth without trust (Kasper et al., 2012).

Trust evolution processes mainly depend on factors that form and influence trust. Notably, Rachel Botsman reviewed the "Trust Stack» model as the process of forming a trust. It means that first, it is necessary to believe in the idea, then trust in the company or platform, and finally, place confidence in individuals or users (Botsman, 2017). Various academic workings suggested that trust cannot be a onedimensional factor. It should be seen through integrity, benevolence, empathy, competence, ability, and 
predictability (Pavlou et al., 2003; Lee and Turban, 2001; McKnight et al., 2002; Urban et al., 1999). Besides, social relations, cultural factors, and experience shape the trust-forming context (Furlong, 1996). Linda Childers Hon and James E. Grunig have identified three dimensions to trust such as integrity, dependability, and competence. From the customer's view, satisfaction is a key factor for the trust-building process (Costabile et al., 2000). The trust concept is evolving while it is shaped by technological progress. The digital economy is expanding in every aspect of our everyday life, where digital platforms and the sharing economy take a central part. Several researchers argued that the sharing economy is managed by trust (Mazzella et al., 2008, Möhlmann, 2016, Botsman, 2017), and trust in strangers is a key factor.

It stands to mention the difference between traditional and digital trust. Digital trust is more complex since it uses technology as a middleman throughout the trading process. Modern studies underline the complicated nature of digital trust, whereas traditional trust primarily focuses on trust in individuals; infrastructure and the underlying control mechanism (technology trust) are also important factors in the digital trust forming process (Ratnasingam et al., 2002). Furthermore, Lee and Turban (2001) highlighted factors in digital trust forming in B2C internet models: trustworthiness of internet merchant, the trustworthiness of internet shopping medium, and contextual factors. Besides, they include other factors and individual trust propensity as key variables in the digital trust-building process. Following the reviews mentioned above, digital trust has similarities with traditional trust in basic trust foundations, but several technological factors also influence it.

Methodology and research methods. The research methodology rests on the trust stack model (Botsman, 2017) discussed in the literature review. Research develops three hypotheses according to each step of the trust stack model. All hypothesis discusses Georgian digital economy. As mentioned above, digital trust could not be considered as a single-dimensional factor. Following the literature review discussed in the previous section and a deep and comprehensive analysis of country characteristics, we came up with different factors to analyze each step of the trust stack in the Georgian digital economy.

Table 1. Research hypotheses

\begin{tabular}{|c|c|c|}
\hline Base Trust Stack Model & Research hypotheses & Factors \\
\hline 1.Trust in the idea & $\begin{array}{l}\text { H1: Digital technologies are accessed and } \\
\text { used by people in Georgia. }\end{array}$ & $\begin{array}{l}\text { Access and usage of digital } \\
\text { technologies }\end{array}$ \\
\hline 2. Trust in the platform & $\begin{array}{l}\text { H2: People are involved in digital } \\
\text { business services; companies offer digital } \\
\text { solutions to individuals in Georgia. }\end{array}$ & $\begin{array}{l}\text { Involvement in digital economy } \\
\text { activities }\end{array}$ \\
\hline 3. Trust in the user (individual) & $\begin{array}{l}\text { H3: Digital trust to other users (product- } \\
\text { service/providers) is formed in Georgia. }\end{array}$ & Individual trust levels \\
\hline
\end{tabular}

Sources: developed by the authors.

Research hypotheses follow the trust stack model. Therefore, firstly, people need to trust that digital technologies are trustworthy and can be used. In the second stage, they should trust the existing platforms and be involved in digital economy activities, i.e., using the Internet for commercial uses. Finally, people need to trust other platform users (other individuals or representatives of companies).

This study used the primary source Inglehart et al. (2014) to gather data. The data was particularly valuable in answering the question about cultural foundations of personal trust. The WVS consists of nationally representative surveys conducted in around 100 countries that contain almost 90 percent of the world's population. The World Values Survey (2010-2014) includes trust indicators for 58 countries. The actual data for Georgia is available only before 2014, but they are not outdated as traditional trust factors require decades to change. Here different indicators describe trustworthiness generally in dealing with people personally, within the family, in the neighborhood, or with strangers. Other primary sources are databases from the National Statistics Office of Georgia (Geostat), including data on digitalization levels, 
digital usage activities, characteristics of e-commerce services, etc. (databases: «Information and Communication Technologies Usage in enterprises», «Information and Communication Technologies Usage in Households»).

Research also uses statistics from "The Digital Intelligence Index», provided by The Fletcher School at Tufts University, and E-Participation" provided by World Economic Forum.

Research also uses statistics from "The Digital Intelligence Index», provided by The Fletcher School at Tufts University, and E-Participation" provided by World Economic Forum.

Results. This part discusses all hypotheses according to statistical overview and digital transformation characteristics in the Georgian economy.

Access and usage of digital technologies. Access to digital technologies is increasing in term of Internet coverage and device usage:

- Internet coverage - $83.8 \%$ of Georgian households have internet access (2020), a $13.8 \%$ increase during the last five years. It is noteworthy that internalization levels in urban centers $(90.7 \%)$ are significantly higher than in rural areas (74.5\%). On the other hand, internet access is available for most enterprises with hired workers $(94.0 \%)$.

- Device usage - Computer access level is $61.8 \%$ in Georgian Households, but numbers have stayed relatively constant during recent years. The reason is the growth of mobile phone usage; $86.5 \%$ of the population (aged $6+$ ) own mobile phones, and $92.9 \%$ use one.

Digital technologies are gradually becoming more popular in Georgia. In 2020,74.0\% of the Georgian population used the Internet (15.5 percentage point growth, between 2015-2020). Of them, 89.2\% were regular internet users, i.e., $66.0 \%$ of the Georgian population are using the Internet almost daily.

Involvement in digital economy activities. The main use of the web is social networking and communication, but the Internet is also used for economic activities. $38.5 \%$ of internet users search for information about goods and services, $34.7 \%$ use internet banking, and only $21.3 \%$ use e-commerce services. E-commerce usage rates are higher in urban areas (27.4\%). The youth population (age 15-29) is the main target consumer segment in the e-commerce sector, with a $37.3 \%$ usage rate.

It stands to mention that $18.4 \%$ of enterprises (companies with hired workers) have their own webpage, but only $2.6 \%$ of enterprises are receiving orders via web pages for goods or services.

Additionally, digital services provided by the government are limited. «E-Participation» is an index by the World Economic Forum that measures online services' use to facilitate the provision of information by governments to citizens. Georgia's score is 0.62 out of 1.0 and ranks 84 th of 141 economies in the 2019 edition of the Global Competitiveness Report.

Individual trust levels. Traditional trust is a general trust between individuals. According to the World Values Survey, in Georgia, only $8.8 \%$ of individuals think that most people can be trusted. Thus, different groups were reviewed by trust levels (completely or somewhat).

Family is still the most trustworthy informal, traditional institution for individuals (99.1\%), where $91.4 \%$ have complete trust in the family. Neighborhoods also stand out by trustworthiness; $85.7 \%$ of individuals have complete trust in their neighbors. $78.5 \%$ of the Georgian population have trust (completely or somewhat) in people they know personally, but most not completely.

In business, there are frequent interactions with strangers, especially in the digital economy. Trust forming is very difficult for a stranger in Georgia - only $16.2 \%$ of individuals have trust in people they have met for the first time. Elderly people (aged 50+) have more trust in strangers than young people (age up to 29$)$, respectively $21.8 \%$ and $12.0 \%$.

Trust in strangers $(16.2 \%)$ is significantly less than trust in people personally known $(78.5 \%)$ and less than half that of trust in large companies $(36.9 \%)$. Therefore, trust in centralized institutions and stays dominant in a tight circle of acquaintances. According to recent statistics and other findings, the discussions all hypotheses are as follows: 
H1: Digital technologies are accessed and used by people in Georgia - Hypothesis is mainly supported. Georgia is moving towards digitalization. Internalization problems have mostly been solved in urban areas with high-speed Internet. But in rural areas, high-speed Internet is very rare. On the positive side, a significant part of the population owns computers or at least mobile phones. Consequently, they can join the global network if a reliable connection is available.

H2: People are involved in digital business services; companies are offering digital solutions to individuals in Georgia - Hypothesis is partially supported. The Georgian business sector widely uses websites and social media, but consumers can mostly get products/services via the Internet. The quality of web pages and digital platforms is not very high.

E-commerce services seem popular with the Georgian youth population, but their usage is limited, although consumers are using e-commerce services. Georgian companies' involvement in e-commerce services is growing. E-banking remains the most popular e-service. Several firms are working in the Georgian market, including sharing economy platforms (which is most interesting for our research), mainly in real estate, the automobile industry, and consumer items. The popularity and diversity of these services are increasing. It is essential to distinguish business transactions fully executed via the Internet from transactions where the Internet only provides marketing or contact information. As usual, C2C transactions (sharing economy) between Georgian buyers and sellers outside the websites are people using traditional trust factors in the process. But some modern platforms are also offering P2P transactions on their website where buyers and sellers from the sharing economy are completing their transactions online. These transactions lead to the establishment of digital trust and digital reputation between decentralized members of the digital sharing economy.

H3: Digital trust to other users (product-service/providers) is formed in Georgia - Hypothesis is partially rejected. Cultural factors have an impact on digital trust but also on building traditional trust. Therefore, traditional individual trust levels could be considered to be a vital component of the digital trust forming process. Cultural foundations of traditional trust are not working towards digital economy goals in Georgia. Thus, putting trust in strangers is a key factor in the digital economy, especially in the sharing economy. However, data analysis shows that trust in strangers is very low in Georgia, lower than in most countries in the same survey. It could result from Soviet history (the age of formal institutional trust) and the 1990s recession when all institutions lost trustworthiness. Unfortunately, trust rates in young people are even lower who are active in the digital world. Trust in strangers is a key factor in establishing trust in digital platforms. Therefore access to digital trust goals has barriers for small companies. On the other hand, trust in large companies is high, meaning they can more easily offer digital products to consumers. Finally, the quality of supported digital tools (customer feedback, digital history, public information, etc.) will be crucial to users' digital trust-building process.

Conclusions. The digital economy is shaping the future of business. Technological progress presents various challenges for all countries and especially for developing ones. Still, the COVID-19 crisis has revealed the potential of the digital economy and created additional incentives to boost online transactions. However, trust stays at the center of the digital economy that encourages people to be more involved in online activity.

Globalization has already made Georgia part of the global digital economy. To fully benefit from its fruits, Georgia has to overcome challenges connected with digital transactions by the following actions:

1. Continuing improvement of essential infrastructure to allow access to digital services. Digital infrastructure (e.g., high-speed network connection) is the focal point for the whole industry to develop and reach higher levels of the value chain.

2. Increasing the rate of internet penetration to cover rural areas. This challenge became more tangible during the recent lockdowns, for example, when students from rural areas could not get e-learning services properly, or people had no opportunity to access online shopping. The digital gap between 
regions is a variety of economic inequality, which is a more actual challenge for many other developing economies.

3. Expanding the number of digital services in the public sector. E-governance models are crucial in the modern policy-making process. It forms trust in public services. In the United Nations e-government Survey, Georgia ranks 65th in the world on the e-government development index. The state sector's contribution is important for every economy.

4. Providing the maximum level of transparency in online government services so that people can generalize this experience to the private sector. Georgia ranks 7 th in the world in ease of doing business. However, it is necessary to promote flexibility in the digital economy. This problem should be more challengeable for countries which business environments are less flexible.

5. Create a legal framework for the digital economy to support transparency and accountability; the digital economy requires specific laws to establish and manage business online.

6. Deliver sound cyber-security and protect citizen privacy. Digitalization will not be an issue if reliable data centers are provided that guarantee high-security levels for both firms and individuals. Online security fears are boosting digital untrust in developing regions worldwide which are slowing the digitalization process. Therefore, digital security should be more priority for countries where the digital economy is just expanding.

Acknowledgements: Article is prepared at Business and technology University (BTU) through the «INITIATIVE 5.0».

Funding: This research received no external funding.

Authors' Contribution: conceptualization, T.Z. and V. C.; methodology, T. Z. and V. C.; formal analysis, T. Z. and V. C; resources, V. C; data curation, T. Z.; writing-original draft preparation, T. Z. and V. C.; writing-review and editing, V. C.; project administration, T. Z.

\section{References}

Arrow, K. J., \& Hurwicz, L. (1972). An optimality criterion for decision-making under ignorance. Uncertainty and expectations in economics, 1. [Google Scholar]

Bhattacharya, R., Devinney, T. M., \& Pillutla, M. M. (1998). A formal model of trust based on outcomes. Academy of management review, 23(3), 459-472. [Google Scholar] [CrossRef]

Botsman, R. (2017). Who can you trust?: How technology brought us together and why it might drive us apart. Hachette UK [Google Scholar]

Botsman, R., \& Rogers, R. (2010). What's mine is yours. The rise of collaborative consumption. [Google Scholar]

Chakravorti, B., Chaturvedi, R. S., Filipovic, C., \& Brewer, G. (2020). Digital in the time of COVID. Digital Planet, The Fletcher School at Tufts University. Retrieved from [Link] Scholar]

Costabile, M., Raimondo, M. A., \& Miceli, G. (2000). A dynamic model of customer loyalty. In IMP Conference, Bath, UK. [Google

EU4Digital. (2021). Georgia. Retrieved from [Link]

Furlong, D. (1996). The Conceptualization of 'Trust' in Economic Thought. [Google Scholar]

Geostat. (n.d.). Information and Communication Technologies Usage in enterprises. Retrieved from [Link]

Geostat. (n.d.). Information and Communication Technologies Usage in Households. Retrieved from [Link]

Groenewegen, J. P. M. (2010). Institutional Economics, an introduction. Palgrave Macmillan. [Google Scholar]

Inglehart, R., Haerpfer, C., Moreno, A., Welzel, C., Kizilova, R., Diez-Medrano, J., Lagos, M., Norris, P., Ponarin, E., \& Puranen, B. (2014). World Values Survey: Round Six - Country-Pooled Datafile Version. Retrieved from [Link]

Kasper, W., Streit, M. E., \& Boettke, P. J. (2012). Institutional economics: Property, competition, policies. Edward Elgar Publishing. [Google Scholar]

Lee, J., \& Moray, N. (1992). Trust, control strategies and allocation of function in human-machine systems. Ergonomics, 35(10), 1243-1270. [Google Scholar] [CrossRef]

Lee, M. K., \& Turban, E. (2001). A trust model for consumer internet shopping. International Journal of electronic commerce, 6(1), 75-91. [Google Scholar]

Luhmann, N. (1988). Familiarity, confidence, trust: problems and alternatives in Gambetta D ed Trust: making and breaking cooperative relations Blackwell. [Google Scholar] 
Mazzella, F., Sundararajan, A., d'Espous, V. B., \& Möhlmann, M. (2016). How digital trust powers the sharing economy. IESE Business Review, 26(5), 24-31. [Google Scholar]

McKnight, D. H., Choudhury, V., \& Kacmar, C. (2002). The impact of initial consumer trust on intentions to transact with a web site: a trust building model. The journal of strategic information systems, 11(3-4), 297-323. [Google Scholar] [CrossRef]

Möhlmann, M. (2016). Digital trust and peer-to-peer collaborative consumption platforms: A mediation analysis. Available at SSRN 2813367. [Google Scholar] [CrossRef]

North, D. C. (1999). Institutions, Institutional Change and Economic Performance, Washington University, St Louis, ch 1, 4, 5 , pp. 3-11, 36-54. [Google Scholar]

Parker, G. G., Van Alstyne, M. W., \& Choudary, S. P. (2016). Platform revolution: How networked markets are transforming the economy and how to make them work for you. WW Norton \& Company. [Google Scholar]

Pavlou, P. A., Tan, Y. H., \& Gefen, D. (2003). Institutional trust and familiarity in online interorganizational relationships. In Proceedings of the European Conference on Information Systems (ICIS) Naples, Italy. [Google Scholar]

Ratnasingam, P., Pavlou, P. A., \& Tan, Y. H. (2002). The importance of technology trust for B2B electronic commerce. In 15th Bled Electronic Commerce Conference eReality: Constructing the eEconomy, Bled, Slovenia. [Google Scholar]

United Nations. (2020). E-Government Survey 2020 - Digital Government in the Decade of Action for Sustainable Development. Retrieved from [Link]

Urban, G. L., Sultan, F., \& Qualls, W. (1999). Design and evaluation of a trust based advisor on the Internet. Interface. [Google Scholar]

Zhghenti, T. (2018). Trust in The Informal Institutions (The Case of Georgia). Proceedings of International Conference on Applied Research In Management, Economics and Accounting. Retrieved from [Link]

Zhghenti, T. (2019). The Importance of Trust in Informal Institutional Development Process (Case of Georgia). Proceedings of International Conference Management, Accounting, Banking, Economics and Business Research (ICMABEBR-19). Retrieved from [Link]

Цотне Жгенті, Ph.D., доцент, Університет бізнесу та технологій, Грузія

Вахтанг Чкареулі, доцент, Університет бізнесу та технологій, Грузія

Розвиток онлайн-бізнесу: формування довіри у цифровому середовищі

Впровадження широкомасштабного локдауну через пандемію COVID-19 у 2020-2021 роках сприяло стрімкій цифровізації бізнес-процесів у всьому світі. Головною детермінантою нарощування обсягів онлайн-транзакцій стає довіра споживачів. Авторами зазначено, що тривале перебування Грузії у складі Радянського Союзу сформувало стереотип негативного ставлення до нововведень та недовіру до них серед суспільства, формальних та неформальних організацій. Тому розвиток онлайн-бізнесу у Грузії вимагає подолання пострадянської свідомості та розвиток цифрових компетенцій серед суспільства. Попри те, що трансформація економічної системи Грузії від централізовано-планової (пострадянська спадщина) до ринкової сприяє поступовому зростанню довіри до інституцій, актуальною залишається проблема недовіри до бізнес-сектору. У рамках даного дослідження проаналізовано процес формування цифрової довіри та виявлено основні перешкоди цифровізації бізнесу в Грузії. Авторами зазначено, що довіра є залежною змінною, на яку впливають цифрові та фізичні операції. Так, науково-технічний прогрес забезпечує низку інструментів для підвищення рівня задоволеності та довіри клієнтів, що сприяє підвищенню рівня їх лояльності. Однак, проблема цифрової безграмотності та низького рівня цифрової безпеки піддають сумніву надійність онлайн-бізнесу. Таким чином, дослідження питань довіри в цифровій економіці $є$ актуальним серед науковців та практиків. Основною метою дослідження $є$ визначення головних проблем при цифровізації бізнесу в Грузії на основі аналізу процесу формування цифрової довіри. Для досягнення поставленої мети застосовано стекову модель довіри для аналізу трьох етапів формування довіри, а саме: довіра до ідеї, довіра до онлайнплатформи та особистості. Відповідно до результатів дослідження виявлено поточні проблеми у формуванні цифрової довіри та завдання для їх подолання. Авторами наголошено, що результати дослідження можуть бути узагальнені для більшості країн, де цифрова трансформація $є$ на порядку денному та особливо країн, які розвиваються та пройшли етап економіко-політичної трансформації.

Ключові слова: цифрова економіка, довіра, цифрові технології, цифровий бізнес, неформальний інститут. 